\title{
A Co-creation of Learning and Teaching Typology: What Kind of Co- creation are you Planning or Doing?
}

\author{
Catherine Bovill, Senior Lecturer in Student Engagement, Institute for Academic \\ Development, University of Edinburgh, Scotland, UK
}

Contact: catherine.bovill@ed.ac.uk

\section{ABSTRACT}

In higher education discourse, reference to co-creation, partnership, and student engagement (to name but a few of the commonly used terms), covers a very wide range of different research and practice. This variety can often be confusing. In response, I present a co-creation of learning and teaching typology, which is a practical resource intended to support students and staff to reflect on, and discuss, their planned and current practice and to be able to identify what particular kind of co-creation they are planning or doing. The typology can be used individually, in small groups or at an institutional level. It has been designed to be adaptable and includes space for additional co-creation variables and responses to be added. Informal feedback from using the typology suggests it has the potential to be (a) a planning tool, (b) a reflective tool, and (c) a mapping tool.

\section{KEYWORDS}

Co-creation, Students as Partners, student-staff partnership, typology, higher education

Over the last five to ten years, we have witnessed a rise in student-staff collaborative research and practice in higher education (Cook-Sather, Bovill, \& Felten, 2014; Healey, Flint, $\&$ Harrington, 2014). There is also growing evidence of many positive outcomes from partnership in, and co-creation of, learning and teaching, including enhanced engagement, motivation, meta-cognitive understanding, and identity formation (Cook-Sather et al., 2014). Yet at times, the literature is confusing due to the variation in terminology used for collaboration (Dunne, 2016) such as Students as Partners, co-creation, students as change agents, and students as producers. Terms are often used interchangeably, and practices categorised within each definition vary. I use the term co-creation of learning and teaching in this paper, as it tends to imply a deeper level of student agency than is often implied by "student engagement," which is sometimes used to refer to a student turning up for class but does not necessarily imply the level of equality that is often emphasised in definitions of "partnership." According to Bovill, Cook-Sather, Felten, Millard, \& Moore-Cherry, (2016, p. 196) "co-creation of learning and teaching occurs when staff and students work collaboratively with one another to create components of curricula and/or pedagogical approaches". 
In an attempt to help people make sense of the variation in co-creation practice, I introduce in this paper a Co-creation of Learning and Teaching typology. I have developed the typology as a means of discussing co-creation with different groups of students and staff. I explain how the typology was created, and then present and explain the typology. I then present some of the informal reactions I have received from students and staff to using the typology, and finally I outline some suggestions of how it might be used in different contexts.

\section{MAKING SENSE OF CURRENT CO-CREATION OF LEARNING \& TEACHING PRACTICE}

My intention in developing the Co-creation of Learning and Teaching typology was to create a tool to support students and staff to discuss, reflect upon, and plan co-creation work. In my own practice and conversations with students and staff, I have found that people often describe their work as co-creation but their work differs from others also describing their work as co-creation. For example, one colleague's co-creation might refer to how she employed a small group of six medical students to design videos about physical activity for use in a flipped classroom approach to a course (Harden \& Fawkner, 2019), while another colleague might be using the term co-creation to refer to how he enabled students in his Classics class to design their own essay title (Cook-Sather et al., 2014). Each of these examples comes within the earlier definition of co-creation of learning and teaching, but involves different numbers of students (six for the former and approximately 30 for the latter), students at different levels of study (one student from each year group for the former and all students in a second-year class for the latter), and different rewards for students (pay for the former and course credit for the latter).

A growing number of frameworks for co-creation, partnership, and student engagement have been proposed to help categorise collaborative research and practice (e.g., Bovill, 2014; Bovill, 2017; Bovill, 2019; Bovill, et al., 2016; Bovill \& Woolmer, 2018; Bryson, Furlonger, \& Rinaldo-Langridge, 2015; Healey et al., 2014; Könings, Bovill, \& Woolner, 2017; Mercer-Mapstone et al., 2017). I have taken elements from these frameworks along with my own ideas, which have emerged from academic development conversations about co-creation with student and staff colleagues, and I have brought these together in the one-page Co-creation of Learning and Teaching typology (see Table 1).

My aim was to create a practical tool for use with students and staff, which would enable colleagues to articulate the different approaches they take to co-creation and why. The questions were informed by my own practice, which led me to suggest some additional co-creation variables missing from the existing published frameworks. The typology includes a list of co-creation variables, presented in the form of questions in the first column of the table, followed by different responses to these questions in the rows, which illustrate the different possible types of co-creation. I will now explain each of the questions within the typology in turn.

\section{Who initiates the co-creation?}

Most teaching and curriculum-related work is initiated by staff, who are often considered to be gatekeepers of the curriculum and responsible for teaching (Bourner, 2004; Bovill, 2014). Student-led initiatives are perhaps more likely where an environment of shared trust, respect, and responsibility has been established and students feel more confident to propose collaborative work, either within or outside the curriculum. 
Table 1. Co-creation of Learning and Teaching Typology

\begin{tabular}{|c|c|c|c|c|c|c|c|}
\hline \multirow{2}{*}{$\begin{array}{l}\text { QUESTION } \\
\text { Who initiates the co-creation? }\end{array}$} & \multicolumn{7}{|c|}{ POSSIBLE RESPONSES } \\
\hline & Staff-led & Student-led & $\begin{array}{l}\text { Staff and } \\
\text { students }\end{array}$ & & & & Other \\
\hline $\begin{array}{l}\text { What is the focus of the co-creation? } \\
\text { (see Bovill \& Woolmer, 2018; Healey et al., } \\
\text { 2014) }\end{array}$ & $\begin{array}{l}\text { Entire curriculum } \\
\text { (co-creation of } \\
\text { the curriculum) }\end{array}$ & $\begin{array}{l}\text { Learning \& } \\
\text { teaching (co- } \\
\text { creation in the } \\
\text { curriculum) }\end{array}$ & $\begin{array}{l}\text { Educational } \\
\text { research \& } \\
\text { evaluation }\end{array}$ & $\begin{array}{l}\text { Disciplinary } \\
\text { research }\end{array}$ & $\begin{array}{l}\text { Wider student } \\
\text { experience }\end{array}$ & & Other \\
\hline $\begin{array}{l}\text { What is the context for the co-creation? } \\
\text { (see Bovill \& Woolmer, 2018; Mercer- } \\
\text { Mapstone et al., 2017) }\end{array}$ & Curricular & Extra-curricular & University-wide & & & & Other \\
\hline $\begin{array}{l}\text { How many students are involved? (see } \\
\text { Mercer-Mapstone et al., 2017) }\end{array}$ & $1-5$ & $6-10$ & $11-20$ & $21-30$ & $31-100$ & $101-500$ & Other \\
\hline $\begin{array}{l}\text { Have you selected students from a larger } \\
\text { group or are you involving a whole class? } \\
\text { (See Bovill, 2019; Bryson et al., 2015) }\end{array}$ & Selected & $\begin{array}{l}\text { Whole } \\
\text { class/group }\end{array}$ & & & & & Other \\
\hline $\begin{array}{l}\text { Which students are involved? } \\
\text { (See Bovill, 2014) }\end{array}$ & Retrospective & Current & Future & & & & Other \\
\hline What year of study are the students in? & Year 1 (UG) & Year 2 (UG) & Year 3 (UG) & Year 4 (UG) & Masters & $\mathrm{PhD}$ & Other \\
\hline What is the scale of the co-creation? & 1 class & Several classes & 1 project & $\begin{array}{l}\text { Several } \\
\text { projects }\end{array}$ & $\begin{array}{l}\text { Faculty/School- } \\
\text { wide }\end{array}$ & $\begin{array}{l}\text { Institution- } \\
\text { wide }\end{array}$ & Other \\
\hline How long does the co-creation last? & Days & Months & Years & & & & Other \\
\hline $\begin{array}{l}\text { What is the role of the student? } \\
\text { (See Bovill et al., 2016) }\end{array}$ & Representative & Consultant & Co-researcher & $\begin{array}{l}\text { Pedagogical } \\
\text { co-designer }\end{array}$ & & & Other \\
\hline $\begin{array}{l}\text { What is the nature of student involvement? } \\
\text { (See Bovill, 2017; Könings et al., 2017) }\end{array}$ & Informed & Consulted & Involved & Partners & Leading & & Other \\
\hline $\begin{array}{l}\text { What is the nature of reward or } \\
\text { recompense given to students? }\end{array}$ & $\begin{array}{l}\text { Payment in } \\
\text { money }\end{array}$ & $\begin{array}{l}\text { Payment in } \\
\text { vouchers }\end{array}$ & Course credit & No payment & Refreshments & & Other \\
\hline Why are you co-creating? & $\begin{array}{l}\text { To improve my } \\
\text { course }\end{array}$ & $\begin{array}{l}\text { To enhance } \\
\text { student } \\
\text { engagement }\end{array}$ & $\begin{array}{l}\text { Aiming for a } \\
\text { socially just } \\
\text { higher education }\end{array}$ & $\begin{array}{l}\text { Impressed by } \\
\text { benefits }\end{array}$ & $\begin{array}{l}\text { Want student } \\
\text { perspectives }\end{array}$ & $\begin{array}{l}\text { To enhance } \\
\text { student's skills }\end{array}$ & Other \\
\hline Other question & & & & & & & Other \\
\hline Other question & & & & & & & Other \\
\hline
\end{tabular}

Bovill, C. (2019). A co-creation of learning and teaching typology: What kind of co-creation are you planning or doing?, International Journal for Students 93 as Partners, 3(2). https://doi.org/10.15173/ijsap.v3i2.3953 


\section{What is the focus of the co-creation?}

Healey et al., (2014) distinguish between partnership work focused on curriculum design, learning teaching and assessment, subject-based research, and scholarship of teaching and learning. They also acknowledge some overlap between these four areas. The typology also distinguishes between "co-creation of the curriculum (co-design of a programme or course, usually before the programme or course takes place) and co-creation in the curriculum (co-design of learning and teaching within a course or programme usually during the course or programme)" (Bovill \& Woolmer, 2018, p. 3). I have also added "wider student experience" because many co-creation projects focus on broad university enhancement, such as campus culture and wellbeing (Johinke et al., 2018).

\section{What is the context for the co-creation?}

The context may be influenced by the perspectives of those engaging in co-creation. For example, a curriculum design team with students and staff co-designing the curriculum might be considered curricular by staff (as it pertains to the curriculum), but extra-curricular by students (who do not usually receive course credit for this co-creation). Other co-creation activity might take place across a university.

\section{How many students are involved?}

Co-creation activities sometimes involve one student, small groups of students, or a whole class of students (a small or large class). Clearly one staff member working with one student will lead to very different co-creation processes and experiences than one staff member working with a whole class of, say, 100 students.

Have you selected students from a larger group or are you involving a whole class?

Related to the last variable about the numbers of students, some co-creation projects involve selecting students from a larger group to work with staff. In contrast, cocreation can take place in the classroom or online teaching spaces between the teacher and the whole class, overcoming the challenges of a selection process.

\section{Which students are involved?}

Drawing on a categorisation from Bovill (2014), which relates to students' programme of study, co-creation can involve students from previous years (retrospective), from the current cohort (current), or from those who are going to be studying a course (future students).

\section{What year of study are the students in?}

I have chosen to represent four years of an undergraduate degree, which is based on my experience in the Scottish higher education system. This can be easily adapted for different higher education systems or specialist degrees.

\section{What is the scale of the co-creation?}

Co-creation can take place in one classroom, initiated by one teacher, or it can be a single project. Co-creation in classrooms can appear to be small-scale examples of cocreation but they may involve many students. Similarly, institutional-level co-creation and partnership schemes are often considered large-scale. Despite involving multiple projects 
and co-ordination occurring at an institutional level, the number of students involved in these schemes can sometimes be modest (Mercer-Mapstone \& Bovill, 2019).

\section{How long does the co-creation last?}

Co-creation initiatives can last for just a few days right through to several years for some work. This will also depend greatly on other variables such as the focus and context of co-creation.

\section{What is the role of the student?}

Drawing on the work of Bovill et al. (2016), four roles are outlined for students: representative (an elected role), consultant (often selected students paid or rewarded in other ways to offer feedback on teaching), co-researcher (students working with staff to investigate subject-based research or research into teaching), and pedagogical co-designer (students co-creating learning, teaching, and curriculum).

\section{What is the nature of student involvement?}

Students can be involved in co-creation in different ways at different stages of cocreation, for example they might be: informed, consulted, involved, partners, or leading work (Bovill, 2017; Könings et al., 2017).

\section{What is the nature of reward or recompense given to students?}

In general where co-creation takes place in the curriculum, as part of a programme of study, students tend not to be paid, but usually receive course credit. In contrast, extracurricular co-creation often attracts payment. If co-creation takes place outside of a programme of study, some students may be disadvantaged and excluded from participating if payment is not offered (Mercer-Mapstone \& Bovill, 2019).

\section{Why are you co-creating?}

This question encourages participants to reflect on their underpinning motivations for co-creating learning and teaching, as our intentions can have a strong influence on how we approach co-creation and the choices we make. There are many different reasons for students and staff to collaborate and a small selection of rationales are included.

\section{Other}

There are two additional rows where colleagues are invited to add other questions that might enable further distinctions in co-creation practice. All of the rows also have an "other" option, in recognition that there may be alternative versions of co-creation that are not captured in the suggested responses. Including the option to add "other" rows and columns was a conscious decision, reflecting my understanding that this is not a perfect, comprehensive, nor static version of co-creation categorisation. I encourage you to adapt and augment the typology to suit your needs.

\section{INFORMAL FEEDBACK FROM USING THE TYPOLOGY}

Co-creation of learning and teaching is not a neat, easily defined concept. I developed the typology in reaction to colleagues' confusion about defining co-creation. The typology is intended to help people to articulate their intentions and make sense of what 
they are doing. I report here on some informal feedback I have received from students and staff in three different settings.

I introduced the typology to approximately 30 "Co-creation Ambassadors" at a "Masterclass in Co-creation" at University College of Northern Denmark (UCN) in Aalborg. The Ambassadors came from different disciplines across the university, and I asked them to tick or colour in the boxes that illustrated the type of co-creation they were currently engaged in. This enabled us to gather a relatively rough snapshot of co-creation practice across the institution. We were able to highlight some predominant practices at UCN: most co-creation focuses on whole-class approaches, and the most common form of reward for students is providing refreshments. Responses to other variables suggested that a wide range of different approaches to co-creation were being used. The typology enabled us to gather an overview of practice, which helped to stimulate some useful discussions about shared practices and areas where UCN might want to develop future co-creation.

In a workshop on co-creation of learning and teaching with a group of 23 students and staff from different disciplines across the University of Edinburgh, I introduced the typology. Many of these colleagues were new to co-creation, although some were more experienced. I asked participants to tick or colour in the boxes of the typology that best represented a current co-creation initiative or one they were planning. Anecdotal feedback from participants included one comment that the typology helped to introduce the complex topic of co-creation to a mixed audience. Another colleague reported finding the typology affirming as it suggested some of her existing practice would be considered to be cocreation, and she hadn't previously thought about her teaching approach as co-creation.

I used the typology at a meeting of the Scottish Higher Educational Developer's Network with 24 academic developers in a short session on co-creation of learning and teaching and the development of graduate attributes. Once again colleagues were asked to plot their current or planned co-creation activity on the typology. Several participants anecdotally shared positive feedback about how helpful they found the typology for thinking about and discussing their practice with others.

Feedback from these three groups highlights that the typology can be used as: (a) a planning tool to consider what kind of co-creation might be the best approach in a particular setting and to think of key questions in the early stages of planning, (b) a reflective tool with questions that help students and staff consider what they are doing in their practice and why they are choosing to co-create in a particular way, and (c) a mapping tool to provide an overview of co-creation practices in a specific context and to find similarities and differences between approaches being used. So far I have not received any negative feedback, nor faced any challenges in using the typology, although I have made some changes since the first version of the typology as colleagues have made useful suggestions, such as adding refreshments as a common form of reward for co-creation after discussions with colleagues at University College Northern Denmark.

The typology enables colleagues to consider a wide range of co-creation variables on one succinct page. It makes it possible to see more clearly that there might be patterns in cocreation practice. The typology also enables conversations to take place about potential benefits or disadvantages of making particular choices in any co-creation practice. The typology may also enable colleagues to present their co-creation work to others more clearly in the future. 


\section{CONCLUSIONS}

The typology is a practical tool intended to prompt conversations about co-creation and engender deeper understanding of the range of co-creation practices that are possible. The typology also offers a language with which to speak about co-creation. My intention is for it to act as an heuristic that can be discussed, critiqued, augmented, and improved upon. I look forward to conversations about the typology as we continue to consider the possibilities of co-creation of learning and teaching.

\section{ACKNOWLEDGEMENTS}

With thanks to Dr Jenny Scoles for comments on an early draft of this work, to Anne Mette Busch and colleagues at University College of Northern Denmark for sharing their inspiring ideas and practices, and to colleagues at the University of Edinburgh and at the Scottish Higher Educational Developers Group who provided useful feedback and reflections on the typology.

\section{NOTE ON CONTRIBUTOR}

Catherine Bovill is a Senior Lecturer in Student Engagement at the University of Edinburgh, Fulbright Scholar 2019-2020 at Elon University North Carolina, and Visiting Fellow (Knowledge Exchange) at the University of Winchester. She is a Principal Fellow of the Higher Education Academy and has published and presented internationally on co-creation of the curriculum and student-faculty partnership in learning and teaching.

\section{REFERENCES}

Bourner, T. (2004). The broadening of the higher education curriculum, 1970-2002: An ipsative enquiry. Higher Education Review, 36(2), 39-52.

Bovill, C. (2019). Co-creation of learning and teaching in higher education: The case for a whole class approach. Manuscript submitted for publication.

Bovill, C. (2017). A framework to explore roles within student-staff partnerships in higher education: Which students are partners, when, and in what ways? International Journal for Students as Partners, 1(1). https://doi.org/10.15173/ijsap.v1i1.3062

Bovill, C. (2014). An investigation of co-created curricula within higher education in the UK, Ireland and the USA. Innovations in Education and Teaching International, 51(1), 1525. https://doi.org/10.1080/14703297.2013.770264

Bovill, C., Cook-Sather, A., Felten, P., Millard, L., \& Moore-Cherry, N. (2016). Addressing potential challenges in co-creating learning and teaching: Overcoming resistance, navigating institutional norms and ensuring inclusivity in student-staff partnerships. Higher Education, 71(2), 195-208. https://doi.org/10.1007/s10734-015-9896-4

Bovill, C., \& Woolmer, C. (2018). How conceptualisations of curriculum in higher education influence student-staff co-creation in and of the curriculum. Higher Education. https://doi.org/10.1007/s10734-018-0349-8

Bryson, C., Furlonger, R., \& Rinaldo-Langridge, F. (2015, July). A critical consideration of, and research agenda for, the approach of "students as partners." Paper presentation presented at the International Conference on Improving University Teaching, Ljubljana, Slovenia. 
Cook-Sather, A., Bovill, C. \& Felten, P. (2014). Engaging students as partners in learning and teaching: A guide for faculty. San Francisco: Jossey Bass.

Dunne, E. (2016). Design thinking: A framework for student engagement? A personal view. Journal of Educational Innovation, Partnership and Change, 2(1).

Harden, J. \& Fawkner, S. (2019, January 24). A student partnership project to enhance curriculum development in medical education [Blog post]. Teaching Matters Blog. Retrieved from: http://www.teaching-matters-blog.ed.ac.uk/a-student-partnershipproject-to-enhance-curriculum-development-in-medical-education/

Healey, M., Flint, A., \& Harrington, K. (2014). Students as partners in learning and teaching in higher education. York: Higher Education Academy.

Johinke, R., Walker, K., Kirkaldy, F., Sinclair, C., Cheng, W. L., Tran, B., Williamson, E., White, G., \& Pillai, S. S. (2018). Therapaws: A partnership between students, staff, and therapy dogs on a university campus. International Journal for Students as Partners, 2(2), 1-10. https://doi.org/10.15173/ijsap.v2i2.3575

Könings K. D., Bovill, C., \& Woolner, P. (2017). Towards an interdisciplinary model of practice for participatory building design in education. European Journal of Education, 52(3), 306-317. https://doi.org/10.1111/ejed.12230

Mercer-Mapstone, L. \& Bovill, C. (2019). Equity and diversity in institutional approaches to student-staff partnership schemes in higher education. Studies in Higher Education. https://doi.org/10.1080/03075079.2019.1620721

Mercer-Mapstone, L., Dvorakova, S. L., Matthews, K. E., Abbot, S., Cheng, B., Felten, P., Knorr, K., Marquis, E., Shammas, R., \& Swaim, K. (2017). A systematic literature review of students as partners in higher education. International Journal for Students as Partners 1(1). https://doi.org/10.15173/ijsap.v1i1.3119 